\section{REFERENCES}

Alley, R.B., D.D. Blankenship, S.T. Rooney, and C.R. Bentley. In press. Sedimentation beneath ice shelves - the view from Ice Stream B. Mar. Geol.

Anderson, J.B., D.D. Kurtz, E.W. Domack, and K.M. Balshaw. 1980. Glacial and glacial marine sediments of the Antarctic continental shelf. J. Geol., 88, 399-414.
Blankenship, D.D., S.T. Rooney, R.B. Alley, and C.R. Bentley. 1989. Seismic evidence for a thin basal layer at a second location on Ice Stream B, Antarctica. (Abstract.) Ann. Glaciol., 12, 200.

Shabtaie, S. and C.R. Bentley. 1987. West Antarctic ice streams draining into the Ross Ice Shelf: configuration and mass balance. J. Geophys. Res., 92(B9), 1311-1336.

\title{
SEASONAL CHANGES IN ICEBERG DISTRIBUTION OFF EAST ANTARCTICA
}

\section{(Abstract)}

by

Ian Allison and George Musil

(Australian Antarctic Division, Channel Highway, Kingston, Tasmania 7050, Australia)

Observations of iceberg numbers and size distributions have been used by various authors to derive estimates of iceberg dissolution rate and of the Antarctic ice-sheet mass discharge (e.g. Budd and others, 1980; Orheim, 1980, 1985; Hamley and Budd, 1986; Wadhams, 1988). A comparison of these studies, however, shows large differences between the distributions, partly because they cover different regions and seasons, or because they use different size categories, but also because there are observational problems including the difficulty of correctly determining the numbers of smaller icebergs, either visually or by radar (Wadhams, 1988; Musil, in press), and the non-standardization of techniques and observers.

In this work we consider iceberg observations made along east-west transects between $85^{\circ}$ and $105^{\circ} \mathrm{E}$ and between $61^{\circ}$ and $63^{\circ} \mathrm{S}$ in 1986-87. Transects were made through this region at three different times of year; in late October and mid-November (MV Icebird) and in mid-January (MV Nella Dan). The first two voyages were made within the pack-ice edge in ice typically of $3-5 / 10$ concentration, whereas the last was in open water. Nearly 1000 icebergs (each within 6 nautical miles of the ships) were routinely observed visually and classified, all by the same observers using standarized techniques.

The iceberg distributions in logarithmically sized categories are shown in Figure 1 for each voyage. While there is little change in distribution between October and November, there is a significant shift to more and smaller icebergs by January. (The distribution of icebergs less than
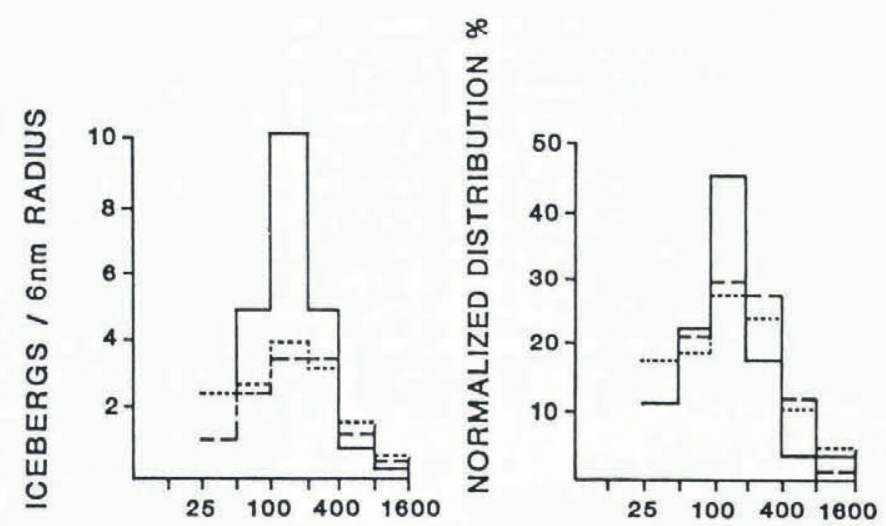

ICEBERG WIDTH (m)

Fig. 1. Observed iceberg-size distributions in late October 1986 (dotted line), mid-November 1986 (dashed line), and mid-January 1987 (solid line).
$50 \mathrm{~m}$ wide should not be considered because of the difficulties of observing these accurately.) It is suggested that the change in distribution occurs after the icebergs are free of the winter pack ice; both warmer temperatures and swell in the open sea result in rapid break-up. Using a method similar to that of Budd and others (1980), the different distributions between October/November and January can be accounted for if $60 \%$ of the icebergs break during the $60 \mathrm{~d}$ period in open water. The median life of icebergs down to $200 \mathrm{~m}$ is as low as 0.15 year once they are in open sea.

The icebergs also show a shift during all seasons to smaller sizes as they move down-stream in the Antarctic Circumpolar Current as shown by Hamley and Budd (1986), and there is a considerable loss in the total observed mass due to wastage and melt (up to $50 \%$ between November and January) in the shift to smaller sizes.

Overall, the observations suggest that careful observation of iceberg-distribution statistics can provide information on dissolution rates and processes, provided that the season of observation is also considered, but the hope that the Antarctic mass balance can be estimated from iceberg distributions with any accuracy is probably optimistic. The episodic calving of giant icebergs from major ice shelves (e.g. the Filchner, Larsen, and Shackleton in 1986, and the Ross in 1987) can significantly affect both the spatial and temporal distribution of icebergs.

\section{REFERENCES}

Budd, W.F., T.H. Jacka, and V.I. Morgan. 1980. Antarctic iceberg melt rates derived from size distributions and movement rates. Ann. Glaciol., 1, 103-112.

Hamley, T.C. and W.F. Budd. 1986. Antarctic iceberg distribution and dissolution. J. Glaciol., 32(111), 242-251.

Musil, G. In press. On iceberg observations using the ship's radar. Iceberg Res.

Orheim, O. 1980. Physical characteristics and life expectancy of tabular Antarctic icebergs. Ann. Glaciol., 1, 11-18.

Orheim, O. 1985. Iceberg discharge and the mass balance of Antarctica. In: Glaciers, ice sheets, and sea level: effect of a $\mathrm{CO}_{2}$-induced climatic change. Report of a workshop held in Seattle, Washington, DC, Department of Energy, DOE/ER/60235-1, 210-215.

Wadhams, P. 1988. Winter observations of iceberg frequencies and sizes in the south Atlantic Ocean. $J$. Geophys. Res., 93(C4), 3583-3590. 